\title{
Life-history, movement, and habitat use of Scylla serrata (Decapoda, Portunidae): current knowledge and future challenges
}

\author{
Hilke Alberts-Hubatsch $\mathbb{D} \cdot$ Shing Yip Lee $\cdot$ \\ Jan-Olaf Meynecke $\cdot$ Karen Diele • \\ Inga Nordhaus $\cdot$ Matthias Wolff
}

Received: 9 February 2015/Revised: 10 June 2015/ Accepted: 24 June 2015/Published online: 11 July 2015

(C) The Author(s) 2015. This article is published with open access at Springerlink.com

\begin{abstract}
The mud crab Scylla serrata is a highly exploited species, associated to mangrove ecosystems in the Indo-West-Pacific. It has a complex life cycle with a dispersing larvae phase, and benthic juveniles and adults. The former are stenohaline depending on high-salinity conditions to survive, whereas the latter are physiologically well adapted to changing temperatures and salinities, conditions that typically occur in mangrove habitats. Movement and habitat use of large juveniles and adults are well studied, and these life stages are known to utilize and move between various habitats within the mangrove ecosystem: intertidal flats as well as subtidal channels and flats. Females undertake long movements from brackish inshore
\end{abstract}

Handling editor: K. W. Krauss

Electronic supplementary material The online version of this article (doi:10.1007/s10750-015-2393-z) contains supplementary material, which is available to authorized users.

H. Alberts-Hubatsch $(\varangle) \cdot$ I. Nordhaus · M. Wolff

Leibniz Center for Tropical Marine Ecology,

Fahrenheitstraße 6, 28359 Bremen, Germany

e-mail: h.alberts.hubatsch@gmail.com

S. Y. Lee - J.-O. Meynecke

Australian Rivers Institute - Coast and Estuaries, School of Environment, Griffith University, Gold Coast Campus, Gold Coast, QLD 4222, Australia

K. Diele

School of Life, Sport and Social Sciences, Edinburgh

Napier University, Edinburgh EH11 4BN, UK waters to waters with oceanic conditions for spawning. Sensory abilities — of early stages and adult stageshave hardly been studied, and little is known about larval and early benthic stages in the wild. Summarizing, the literature revealed substantial gaps in the understanding of the spatiotemporal dynamics of the different life stages and of the clues that trigger recruitment, movement, and other behavior. This is the first comprehensive review on the life history, movement patterns, habitat use, and systemic role of $S$. serrata with emphasis on the respective life stages and geographic differences. We emphasize the need for further research into these processes as a basis for the sustainable management and conservation of this species.

Keywords Behavior - Life-cycle $\cdot$ Habitat shift . Ontogenetic shift

\section{Introduction}

The highly valued mud crab Scylla serrata (Forskål, 1775) (Portunidae) is widely distributed throughout the Indo-West-Pacific (IWP) region (Keenan et al., 1998), where it is closely associated with mangrove forests. S. serrata has a substantial share in industrial and artisanal fisheries throughout its distribution, and fishing effort and landings have drastically increased in the last decades (Allan \& Fielder, 2003; FAO, 2012). The global catch rose from approx. $10,000 \mathrm{t}$ in 
1990 to 40,000 $\mathrm{t}$ in 2012, and there was a concurrent increase in aquaculture production from approx. 4000 to $175,000 \mathrm{t}$ (FAO, 2012). Despite efforts taken to establish sustainable aquaculture of this species, indications of overfishing (Naylor et al., 2002; Ewel, 2008) have led to the establishment of protected areas and fishery limitations in some countries (Australia; Butcher et al., 2003).

Scylla serrata has been studied since the 1940s, and more than 590 research papers, theses, and reports have been published, the majority (67\%) after the revision of the genus in 1998 (Keenan et al., 1998). Until then, S. serrata and its co-species $S$. tranquebariqua, S. paramamosain, and S. olivacea that often occur in the same habitats were frequently mistaken as one species (see "Taxonomy" section). Despite its economic importance and the vast number of publications, basic aspects of the biology and ecology of $S$. serrata for optimizing its conservation and management, e.g., larval dispersal and habitat choice, are not yet well understood. There is also no peer-reviewed review focusing on the general biology and ecology of $S$. serrata that would help identify gaps of knowledge and guide future efforts of researchers and managers. Many publications have been published as non-peerreviewed reports or technical papers with limited circulation.

This review presents available information on lifehistory, population dynamics, movement, and habitat use of $S$. serrata with an emphasis on regional differences to facilitate predictions on possible changes due to climate change and facilitate local management. Information from both peer-reviewed publications and unpublished reports (i.e., theses and technical reports) is included. The term "S. serrata" was used to search in 'title' or 'topic' in the database ISI Web of Science, resulting in $>1100$ publications. These were sorted, and publications not containing S. serrata in the title or abstract were discarded. Due to the long confusion of the classification of the genus Scylla, it is often difficult to ascertain the species in publications prior to 1998 (see "Taxonomy" section). To avoid stating information that may relate to other Scylla species instead of S. serrata, we only considered publications from early years from study regions where this particular species is the only Scylla species known to occur, i.e., South-East Africa, southern East Australia, South Indo-Pacific Islands ("Geographical distribution" section; Fig. 1; Appendix Table 1). Only S. serrata is considered here and referred to as the "mud crab". A great proportion of the literature available is about physiological aspects and topics related to aquaculture, which is not in the focus of our work and thus not included in this review, except few technical papers dealing with aspects of development (life-history) and tolerances toward natural parameters.

\section{Taxonomy}

The portunid crab $S$. serrata was first described by Forskål in 1775 as Cancer serratus from Jiddah, Red Sea. It is a widespread species occurring in coastal tropical and subtropical regions in the whole IndoPacific region. Estampador (1949) was the first to recognize three different species within the genus Scylla in the Philippines on the basis of variations in size, color, and shape: S. serrata (Forskål, 1775), S. oceanic (Herbst, 1796), and S. tranquebarica (Fabricius, 1798). S. serrata var. paramamosain was regarded as a variation of $S$. serrata. This classification was accepted for several decades, except for some obscurities regarding the clear differentiation of species and variations (Serene, 1952). Kathirvel \& Srinivasagam (1992) also noticed the occurrence of several species of Scylla in India, but considered $S$. oceanica as a synonym of $S$. tranquebarica. Others recognized $S$. paramamosain as an additional species in Papua New Guinea (Quinn \& Kojis, 1987) and Western Australia (Taylor, 1984). Due to these uncertainties some authors referred to S. serrata as a single species with different morphs (Stephenson \& Campbell, 1959; Perrine, 1978).

The existence of three distinct species (S. serrata, $S$. tranquebarica, and $S$. oceanica) was already noted by Fuseya and Watanabe (1996) in Japan on the basis of differences in three genetic loci (EST, LAP-2, and SOD). Keenan et al. (1998) revised the genus Scylla, combining genetic and morphometric data. Allozyme electrophoresis and analysis of mitochondrial DNA sequences (COI I and 16 S RNA) revealed four distinct species of Scylla, which are now generally accepted: $S$. serrata (Forskål, 1775), S. tranquebarica (Fabricius, 1789), S. olivacea (Herbst, 1796), and S. paramamosain (Estampador, 1949) (Fuseya \& Watanabe, 1996; Keenan et al., 1998; Klinbunga et al., 2000; Imai et al., 2004; Fuseya et al., 2007; Lin et al., 2007; Ogawa et al., 2011; Mandal et al., 2014). 


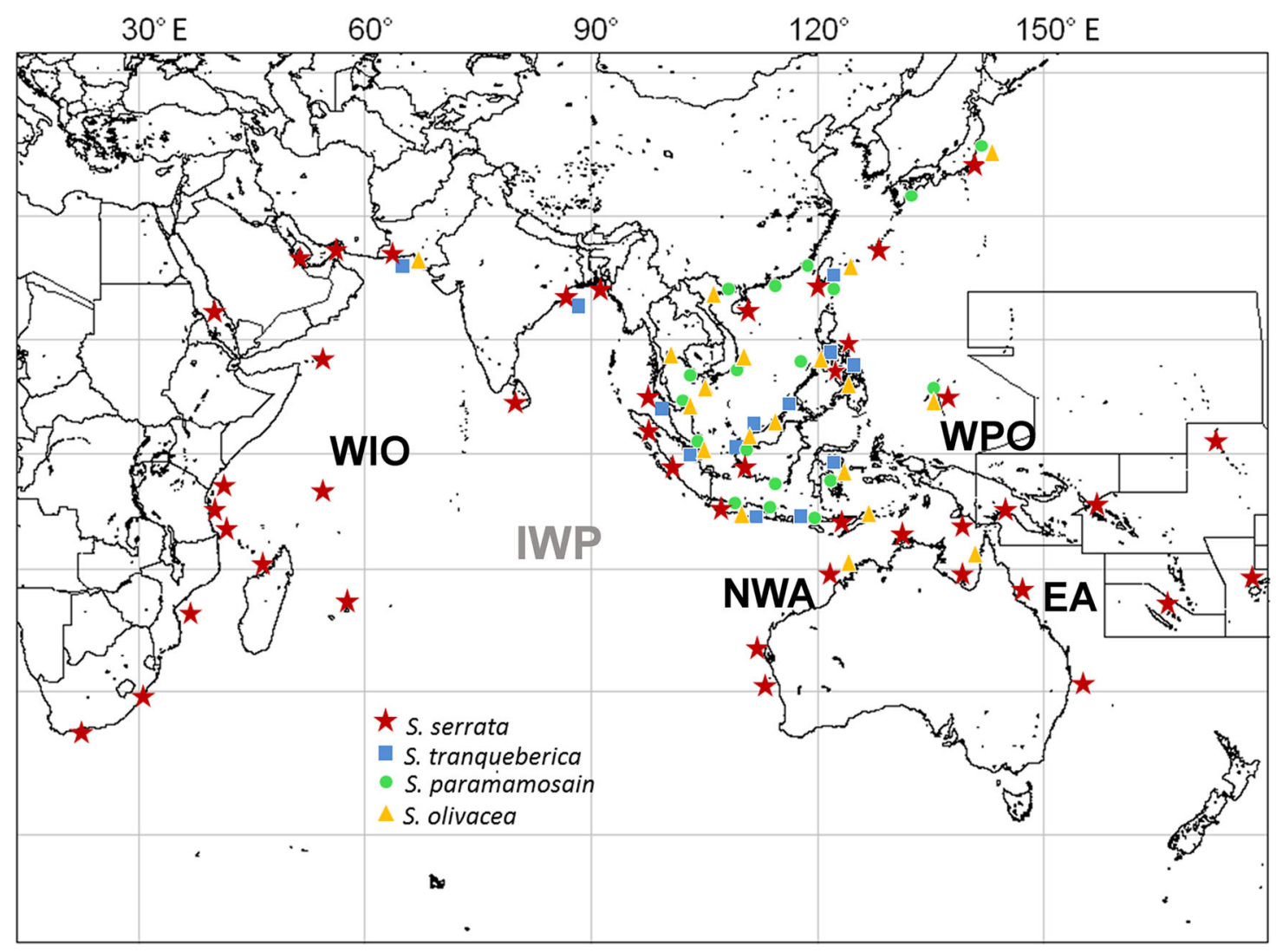

$45^{\circ} \mathrm{N}$

$30^{\circ}$

$15^{\circ}$

$0^{\circ}$

$15^{\circ}$

$30^{\circ}$

$45^{\circ} \mathrm{S}$

Fig. 1 Distribution of the four Scylla species. Not shown: Hawaii with Scylla serrata populations. IWP: Indo-West-Pacific (whole area), WPO: Western Pacific Ocean, EA: Eastern

Despite the existence of identification keys, morphological identification fails in some cases. A presumed Scylla hybrid from Japan with ambiguous morphological characters was identified to be an offspring of female $S$. olivacea and a male $S$. serrata by analyzing mitochondrial and nuclear DNA (Imai \& Takeda, 2005). Individuals from Indonesia are also sometimes hard to be identified due to the lack of distinct morphological features (I. Nordhaus, pers. observation).

\section{Geographic distribution}

Scylla serrata is the widest spread species of the genus Scylla. It can be found in tropical and subtropical coastal regions of the IWP including the southern coast of South Africa (34 $\mathrm{S}$ ) (Du Plessis, 1971), the east coast of Africa (Le Reste et al., 1976; Barnes
Australia, NWA: North-Western Australia, WIO: Western Indian Ocean. Scale: 1: $11,000,000$ at latitude $0^{\circ}$; a table with references can be found in Appendix 1

et al., 2002; Davis et al., 2004; Fondo et al., 2010; Macia et al., 2014), the Red Sea (Keenan et al., 1998), Gulf of Aden (Simões et al., 2001), the Arabian/ Persian Gulf (Hogarth \& Beech, 2001; RezaieAtagholipour et al., 2013), South-east and East Asia (Bight of Bengal, 19-2 ${ }^{\circ} \mathrm{N}$, Mohanty et al., 2006; Zafar et al., 2006; Indonesia, $5^{\circ} \mathrm{N}-10^{\circ} \mathrm{S}$, Sugama and Hutapea, 1999; Nordhaus et al., 2009), the northern Philippine Sea, $\left(34^{\circ} \mathrm{N}\right)$ (Imai et al., 2004), and Australia (Keenan et al., 1998). It also occurs around oceanic islands of the Indo-Pacific: Marianas, Fiji, Samoa Islands (Keenan et al., 1998), and Seychelles, Maldives, and Mauritius (Gopurenko et al., 1999; Anand et al., 2006; Fratini et al., 2010). The species was introduced to the Hawaiian Archipelago between 1926 and 1935 and has since then become an established population (DeFelice et al., 2001). Scylla serrata occurs in areas up to $38^{\circ} \mathrm{S}$, whereas the other three species are centered around the equator. Scylla 
tranquebarica, $S$. olivacea, and $S$. paramamosain are distributed on the Asian continental shelf, and only $S$. olivacea can be found in northern parts of Australia (Keenan et al., 1998; Fig. 1). Referring to the literature after 1998, the latter three species dominate the coastal areas of the southern China Sea and the Java Sea, whereas $S$. serrate is hardly found here (Keenan et al., 1998; Sugama \& Hutapea, 1999; Overton, 2000; MacIntosh et al., 2002; Ikhwanuddin et al., 2011).

Analysis of mitochondrial CoxI genes revealed at least three distinct genetic stocks of $S$. serrata in the Indo-Pacific region: Western Indian Ocean, Eastern Australia; and Western Pacific Ocean (WPO), NorthWestern Australia (Fratini et al., 2010, Fig. 1). The Australian populations can be separated into two distinct clades (northern and eastern populations) divided by the Torres Strait (Gopurenko \& Hughes, 2002). Local mud crab populations are not genetically distinct from each other, but can differ in phenotype (e.g., smaller sizes for southern distribution limit). The larvae have high dispersal potential during the planktonic life stages (16-75 days depending on environmental conditions, Baylon 2010), which is driven by regional and global currents. This enables $S$. serrata to connect with other geographic areas and expand to new habitats, resulting in panmixis of the species (Hill, 1994; Gopurenko et al., 1999, 2003).

Furthermore, genetic analyses suggest colonization by mud crabs of the IWP through propagules deriving from the WPO (Gopurenko et al., 1999; Fratini et al., 2010). The most ancestral haplotype is found in the Red Sea; the colonization of the IWP region seems to have its origin in a rapid single radiation through the Pleistocene (Gopurenko et al., 1999). The occurrence of a common haplotype from the eastern Australian clade in few individuals in the radically divergent north-western Australian clade as well as the existence of a haplotype in south-east China connecting these two Australian clades could be an indicator of humanmediated translocation (Fratini et al., 2010).

\section{Larval development}

The larvae of S. serrata hatch in offshore areas where they undergo five developmental stages (stage I-V; Delathiere, 1990). The survival and developmental time of the larvae strongly depend on water temperature and salinity (Hill, 1974; Hamasaki, 2003;
Nurdiani \& Zeng, 2007; Baylon, 2010). Laboratory experiments showed that all larval stages of $S$. serrata need high salinities and intermediate-to-warm temperatures for survival, with optimum salinities of 25-30 (practical salinity units) and optimum temperatures of $26-30^{\circ} \mathrm{C}$ (Hamasaki, 2003; Nurdiani \& Zeng, 2007; Baylon, 2010), as reported for other tropical and subtropical crab species (Anger, 2001). The first zoeal stage does not survive salinities below 15-17.5 (Hill, 1974; Baylon, 2010) and temperatures $\leq 20^{\circ} \mathrm{C}$ (Baylon, 2010). This explains the offshore migration of the females as the salinity in estuaries often fall below 20 (see"Female spawning migration" section). The last zoeal stage (stage V) still needs higher salinities and temperatures to successfully metamorphose into the megalopa stage (Baylon, 2010). Even though the megalopa stage shows increased tolerance towards salinity (15-45) and low temperature $\left(20^{\circ} \mathrm{C}\right)$, it still does not develop into the first crab stage at salinities below 15 (Baylon, 2010). The physiological optima suggest that settlement and metamorphosis into the first crab stage occur in waters with intermediate-tohigh salinities.

The results of larval rearing studies in aquaculture suggest that the optima of temperature at optimal salinities (25-30) differ slightly for the larvae from different areas: Hill (1974) revealed higher larval mortality at temperatures above $25^{\circ} \mathrm{C}$ in South Africa, whereas in Japan (Hamasaki, 2003) and Indonesia (Nurdiani \& Zeng, 2007), best survival rates were reached at 28 and $29^{\circ} \mathrm{C}$, respectively. Whether these differences exist due to different sampling techniques or are actual differences in populations or phenotypic plasticity has not been investigated.

While dispersal and recruitment of many coastal brachyuran crab larvae are triggered by diurnal and tidal patterns as well as hydrological variables (DeVries et al., 1994; Macintosh et al., 1999; Pineda et al., 2007), no such patterns could be detected to date for $S$. serrata, due to insufficient sampling effort.

The behavior and ecology of mud crab larvae have been studied using hatchery-reared larvae. Webley et al. (2009) showed that laboratory-reared megalopae did not select between different habitats (mud, sand, seagrass), whereas early juveniles expressed strong preferences for seagrass. This suggests that megalopae do not benefit from preferring one of the habitats or do not depend on encountering these, whereas they seem to benefit from inhabiting seagrass as early juveniles 
(Webley et al., 2009). This result can be seen as an indicator for post-settlement behavior, but this aspect should be further investigated, since the preference for seagrass could also be an indicator for preferences for structured or sheltered habitats in general.

\section{Juvenile mud crabs}

After molting into the first crab stage, the tolerance toward lower salinities increases (5-45; Ruscoe et al., 2004, Baylon 2010). The activity of early crab stages ceases at temperatures below $20^{\circ} \mathrm{C}$, but the crab survives these temperatures $\left(\leq 20^{\circ} \mathrm{C}\right)$ and recovers when transferred back into warmer water (Baylon, 2010). The increased tolerance toward changes in salinity and low temperatures with size facilitates movement into estuarine habitats, where these factors vary substantially.

Juveniles (3-99 $\mathrm{mm} \mathrm{CW}$ ) are resident in the upper intertidal and remain there during low tide (Hill et al., 1982; Alberts-Hubatsch et al., 2014; Mirera, 2014, see Appendix Table 2). Heasman (1980) found crabs hiding under stones (tiles) in the upper intertidal zone in Moreton Bay, south-east Queensland. In the St. Lucia lagoon, South Africa, juvenile crabs (20-85 mm) were captured in shallow waters among macrophytes (Hill, 1979a), suggesting that juvenile S. serrata use habitats where they are protected from large aquatic predators. In northern New South Wales, Australia, early benthic stage $S$. serrata (3-30 mm CW, Fig. 2 III.) were found in upper intertidal areas between pneumatophores of Avicennia marina near the mangrove fringe at low tide, where they bury in the soft mud (Alberts-Hubatsch et al., 2014). In east Africa, this stage was predominantly found on upper intertidal flats landward from the mangrove belt at night moving to subtidal habitats during the day (Mirera, 2014). The very first juvenile stage (3-4 mm CW) was found on upper subtidal mud areas seaward to the mangrove fringe in Australia, which might indicate a settlement in subtidal areas and post-settlement relocation toward the mangrove habitat (Alberts-Hubatsch et al., 2014). In general, these ontogenetic shifts in habitat use, i.e., occupying different microhabitats within the adult habitat, can be seen as a mechanism to avoid interspecific predation and cannibalism by larger conspecifics (AlbertsHubatsch et al., 2014).
Movement, habitat use, and activity of adult mud crabs

Adult mud crabs generally inhabit muddy estuaries and enclosures in mangrove ecosystems that are influenced by tidal waters (Arriola, 1940; Brown, 1993; Appendix Table 2). In Deception Bay, southeast Queensland, Hill et al. (1982) studied the use of different habitats by different life stages. Large adults $(\geq 150 \mathrm{~mm} \mathrm{CW}$ ) were predominantly distributed in the subtidal with peak abundances in the summer season (January to April; Hill et al., 1982). Some were also found in intertidal areas where they occasionally inhabit burrows at low tide (Arriola, 1940; Le Reste et al., 1976; Brown, 1993). Female crabs rather bury in the mud than seeking shelter in burrows, so the majority of crabs found in burrows are males (Perrine, 1978; Ewel et al., 2009). The reason for the use of burrows remain unclear, since crabs do not return to the same burrows and do not seem to display homing behavior (Ewel et al., 2009). It has not been investigated, if burrowing mud crabs display different movement patterns from those of crabs living in subtidal creeks. Smaller crabs (100-149 mm CW) are hardly found in burrows and inhabit subtidal waters only at low tide and move into the intertidal zone at high tide with peak abundances from spring to autumn (September-March; Hill et al., 1982).

The movement of mud crabs seems to be closely related to the kind of habitat they live in (Hyland et al., 1984). In general, crabs ( $>100 \mathrm{~mm} \mathrm{CW})$ that live in enclosed habitats such as narrow mangrove-fringed creeks, normally do not move more than $1 \mathrm{~km}$ (Hill, 1975; Perrine, 1978; Hyland et al., 1984; Bonine et al., 2008), whereas in southern Moreton Bay, Queensland, crabs that are found in open environments like intertidal flats in open bays show larger movement (average $3.7 \mathrm{~km}$ ) (Hyland et al., 1984). It is suggested that these different distances of routine movement (daily movements, e.g., foraging activity) are dependent on the availability of alternative feeding grounds at high tide. Isotope studies in Kosrae showed that even though the majority of local mud crab populations reside in their local mangrove area, some populations move regularly between mangrove forests and adjacent reef flats and seagrass meadows $(<1 \mathrm{~km}$ distance) for feeding (Demopoulos et al., 2008). In narrow creeks, there is only a limited intertidal zone, whereas in the open environment, more and larger 


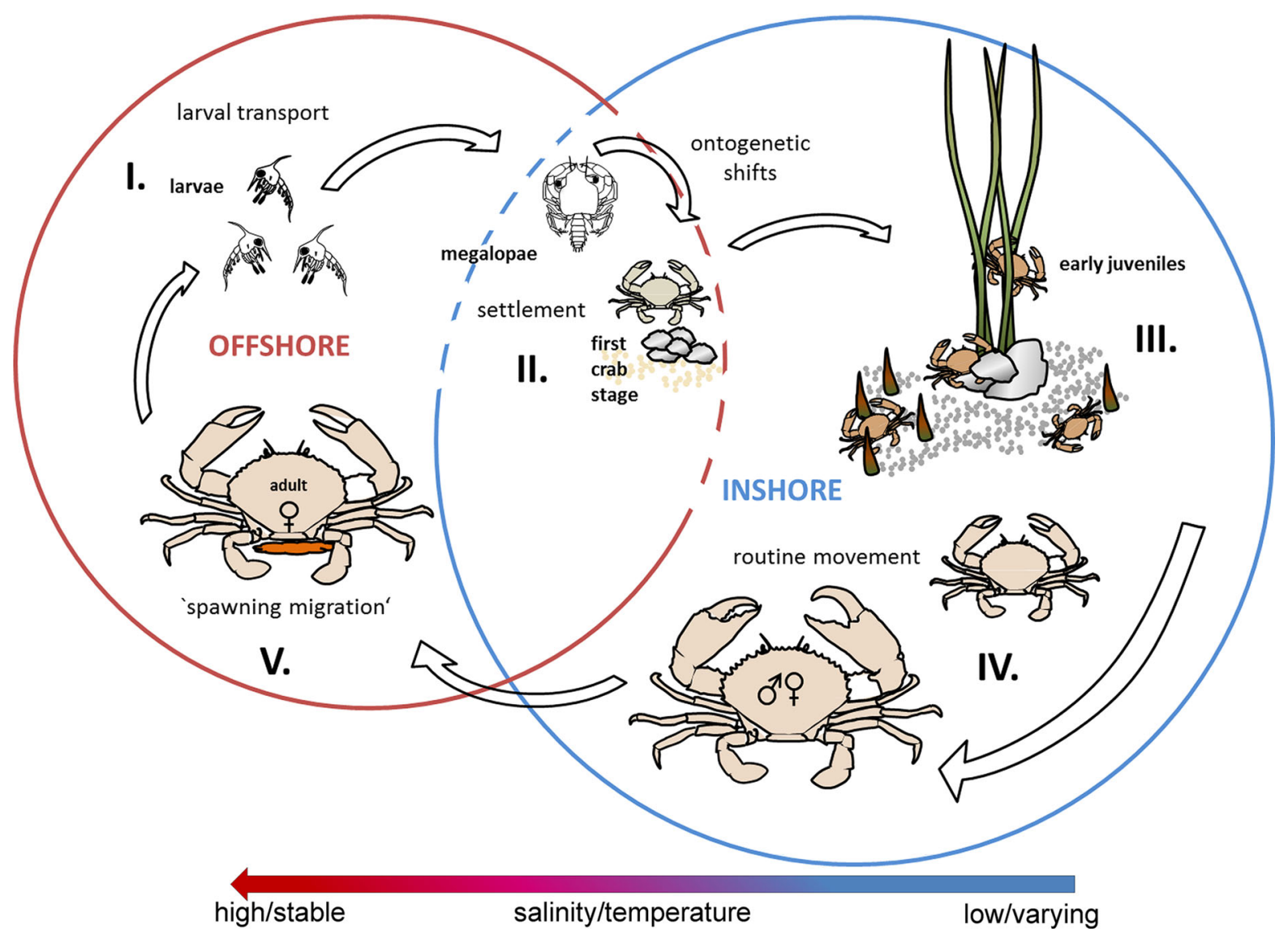

Fig. 2 Schematic drawing of the life cycle of Scylla serrata. The arrow indicates the gradient for salinity (from low/varying to high/ stable) and temperature (from varying to stable)

intertidal flats are present, which provide alternative feeding grounds at high tide and help to avoid intraspecific competition (Hyland et al., 1984) and cannibalism. Recent studies show that movement can be influenced by the seascape and environmental conditions: Adult mud crabs may display stronger seaward movement from enclosed estuarine habitats toward open bay areas, to avoid conspecifics ('demographic diffusion'; Steneck, 2006; Alberts-Hubatsch, unpublished data). Increased freshwater flow during the rainy season may also enhance the activity of mud crabs and therefore trigger their movement (Butcher et al., 2003; Meynecke et al., 2010; Alberts-Hubatsch pers. observation).

Mud crabs are well adapted to warm temperatures $\left(20-30^{\circ} \mathrm{C}\right)$ in the tropical and subtropical regions, but become inactive at low temperatures. Fishermen in Australia have recognized drastic decreases in catch rates, when water temperatures drop to $20^{\circ} \mathrm{C}$ or exceed $35^{\circ} \mathrm{C}$ (Meynecke et al., 2010, unpubl. data). The majority of crabs showed decreased movement and general activity with decreasing temperatures (below $16^{\circ} \mathrm{C}$ ), indicating that mud crabs stay inactive during the colder seasons in subtropical regions (Hill, 1980). An attempt of acclimating mud crabs to water temperatures of $10^{\circ} \mathrm{C}$ failed with most crabs dying (Hill, 1980).

Larger juveniles and adults are strongly euryhaline, thus tolerating broad ranges of temperature and salinity: adult mud crabs survived experimental salinities between 1 and 42 in Malaysia (Davenport \& Wong 1987) and even remained active from 2 to 56 in a South African estuary (Hill, 1979a). The lethal experimental salinity was 64.9 (Hill, 1979a). Mud crabs show strong osmoregulatory responses to changing salinities (Davenport \& Wong, 1987; Chen 
\& Chia, 1996b) and express metabolic responses toward extreme high or low salinities (e.g., nitrogen excretion; Chen \& Chia, 1996b).

Dependence on large-scale climate patterns was shown in Australia where mud crab populations seem to be strongly influenced by the Southern Oscillation. A high Southern Oscillation Index (La Niña) causes cool temperatures and rainfall, inducing high productivity in coastal areas and estuaries that can positively affect the occurrence and reproduction of the mud crab (Meynecke et al., 2006, 2010, 2012; Meynecke \& Lee, 2011).

\section{Female spawning migration}

The spawning migration (Fig. 2, V.) of mud crabs is poorly understood. The absence of ovigerous female mud crabs in brackish waters (Le Reste et al., 1976) indicates that they leave their usual habitat for spawning. In accordance with the findings of ovigerous mud crabs in bottom trawls while fishing for prawns offshore, it was concluded that female mud crabs move long distances (up to $>95 \mathrm{~km}$ ) offshore for spawning (Hill, 1994). Other studies noticed ovigerous females in shallow lagoons, bays, and inlets (Arriola, 1940; Brick, 1974; Prasad \& Neelakantan, 1989), indicating that the spawning migration might depend on hydrological features rather than topographic features. However, to date it was not possible to track the exact movement of gravid females to their spawning grounds. It can only be assumed that female mud crabs seek habitats with stable abiotic conditions with high salinity and temperatures for hatching the larvae. The stable environment maximizes the survival rate of larvae, and the currents facilitate dispersal (see "Larval development" section).

The time of the spawning season varies over different geographic regions. Some authors suggested that the timing of the spawning season is related to latitude and there with the climate zones (tropics, subtropics), but a summary of the different spawning seasons does not reveal such a pattern (Table 1). In most regions, the spawning season coincides with the rainy season, but there are some exceptions (e.g., Madagascar and Hawaii, Brick 1974; Le Reste et al., 1976; Table 1), which makes a link with warm temperatures more likely (Perrine, 1978).

\section{Maturity and mating}

Maturity of S. serrata starts at different sizes in different geographic regions (Tables 2, 3). Some authors (Quinn \& Kojis, 1987; Robertson \& Kruger, 1994) suggested that the different maturation sizes depend on the latitudinal distribution of the crabs, resulting in a faster maturation in tropical regions. However, these conclusions might actually derive from the different size classes of the various Scylla species, since these assumptions were made before the revision of the species (see "Taxonomy" section). Nevertheless, in recent research, different sizes at maturity were observed for $S$. serrate at different locations. In both males and females, a distinction between physiological, morphological, and functional maturities can be made. Physiological maturity in males is characterized when spermatophores develop in the vas deferens after the pubertal molt, but the external appearance of the crab might still be the one of an adolescent/juvenile crab (Robertson \& Kruger, 1994; Knuckey, 1996). Once the male develops large claws, morphological maturity is reached (Knuckey, 1996). Functional maturity describes the ability to successfully mate, which is indicated by 'mating-scars' on the sternum and first pair of walking legs of the male. Even though some adolescent males have mated, functional maturity was far more prevalent in morphologically mature males. In South Africa, males reach physiological maturity at smaller sizes than in Australia (92 vs. $110 \mathrm{~mm} \mathrm{CW}$, respectively), and size at functional maturity seems to vary due to the geographic region (Table 2).

In females, physiological maturity is reached during the last pubertal molt when the ovaries are fully developed. In contrast to males, the functional maturity is often reached at the same time as physiological maturity, since successful mating can already occur during the last pubertal molt when the female is soft-shelled (see below). Morphological maturity is characterized by the development of a mature abdominal flap (wider and more rounded than in adolescent females, Robertson \& Kruger, 1994) and sometimes by the ability of extruding eggs (Hill, 1975). Therefore, comparing female sizes at maturity from different geographic regions can be confusing, since some authors use the shape of the abdominal flap as indicator for maturity, whereas others define maturity by the ability to mate or extrude eggs 
Table 1 Different spawning seasons of Scylla serrata in relation to latitude

\begin{tabular}{|c|c|c|c|c|}
\hline Location & Latitude & Peak spawning season & $\begin{array}{l}\text { Year- } \\
\text { round? }\end{array}$ & Reference \\
\hline Hawaii & $21^{\circ} \mathrm{N}$ & May-October (summer, dry season) & No & Brick (1974) \\
\hline Philippines & $15^{\circ} \mathrm{N}$ & End of May to middle of September & Yes & Arriola (1940) \\
\hline Karwar, India & $14^{\circ} \mathrm{N}$ & Two peaks: Dec-Mar and Sept-Nov & Yes & $\begin{array}{l}\text { Prasad \& Neelakantan } \\
\quad(1989)\end{array}$ \\
\hline Andaman Sea, Thailand & $8^{\circ} \mathrm{N}$ & Late rainy season (Oct-Feb) & Yes & Poovachiranon (1992) \\
\hline Negombo, Sri Lanka & $7^{\circ} \mathrm{N}$ & Two season: April and August & No & $\begin{array}{l}\text { Jayamanna \& Jinadasa } \\
\text { (1993) }\end{array}$ \\
\hline Ramisi River, Kenya & $4^{\circ} \mathrm{S}$ & Possible peak in 2 nd half of the year & Yes & Onyango (2002) \\
\hline $\begin{array}{l}\text { Labu estuary, Papua New } \\
\text { Guinea }\end{array}$ & $6-7^{\circ} \mathrm{S}$ & Two peaks: April-June and Sept-Oct & Yes & Quinn \& Kojis (1987) \\
\hline Tropical (North) Australia & $11-15^{\circ} \mathrm{S}$ & Rainy season: November-February & No & Hill (1994) \\
\hline Madagascar (North-West) & $14^{\circ} \mathrm{S}$ & $\begin{array}{l}\text { Two seasons: dry season (July/Aug), rainy } \\
\text { season (Jan) }\end{array}$ & $\begin{array}{l}\text { Not } \\
\text { specified }\end{array}$ & Le Reste et al. (1976) \\
\hline Queensland, Australia & $28^{\circ} \mathrm{S}$ & October-March & No & Heasman et al. (1985) \\
\hline Natal, South Africa & $29^{\circ} \mathrm{S}$ & Late spring-early autumn & Yes & $\begin{array}{l}\text { Robertson \& Kruger } \\
\text { (1994) }\end{array}$ \\
\hline Natal, South Africa & $29^{\circ} \mathrm{S}$ & July/August & Yes & Davis et al. (2004) \\
\hline Knysna, South Africa & $34^{\circ} \mathrm{S}$ & November-April & No & Du Plessis (1971) \\
\hline
\end{tabular}

Table 2 Size at physiological and functional maturity of male Scylla serrata in relation to latitude

\begin{tabular}{lllll}
\hline Location & Latitude & Physiological maturity CW & Functional maturity CW & Source \\
\hline Pohnpei & $6-7^{\circ} \mathrm{N}$ & & $120-130\left(130-150^{*}\right)$ & Perrine (1978) \\
Tropical Australia (north) & $11^{-14^{\circ} \mathrm{S}}$ & 110 & $125\left(140-160^{*}\right)$ & Knuckey (1996) \\
New Caledonia & $20-22^{\circ} \mathrm{S}$ & 129 & & Delathiere (1990) \\
Moreton Bay, Australia & $28^{\circ} \mathrm{S}$ & & $145\left(164^{*}\right)$ & Heasman (1980) \\
South Africa & $29^{\circ} \mathrm{S}$ & 92 & $115-119$ & Robertson \& Kruger (1994) \\
South Africa & $32^{\circ} \mathrm{S}$ & & 123 & Robertson (1996) \\
South Africa & $34^{\circ} \mathrm{S}$ & & 141 & Hill (1975) \\
\hline
\end{tabular}

Size measured as carapace width $(\mathrm{CW})$ in $\mathrm{mm}$

* Size at $50 \%$ maturity

(Table 3). However, there are differences depending on the geographic region, e.g., the smallest size at maturity (regarding the abdominal flap) is $102 \mathrm{~mm}$ CW in Madagascar (Le Reste et al., 1976), and the minimum size reported from Australia is $138 \mathrm{~mm} \mathrm{CW}$ (Heasman, 1980, Table 3).

The gonads (ovaries/testes) of mud crabs lie below the carapace as paired H-shaped organs. The different developmental stages of the gonads are shown in Tables 4 and 5 . In both sexes, the maturity stages can be identified by different size and coloration of the gonads (Shanmugam \& Bensam, 1980; Prasad \& Neelakantan, 1989; Poovachiranon, 1992; Robertson \& Kruger, 1994; Quinitio et al., 2007).

Mating occurs when the mature (or maturating) female is in the verge of molting. The male uses its walking legs to gently grab the female by its carapace and keeps hold to her until she molts and is softshelled. Then he turns her around, both open their ventral flap, and the male inseminates the female by depositing the spermatophore into the female's spermathecae by inserting his gonopodia into the female's 
Table 3 Size of female Scylla serrata at different maturity classifications in relation to latitude

\begin{tabular}{|c|c|c|c|c|c|c|}
\hline Location & Latitude & $\begin{array}{l}\text { Ovary } \\
\text { development }\end{array}$ & Ovigerous & Mating & $\begin{array}{l}\text { Mature abdominal } \\
\text { flap }\end{array}$ & Reference \\
\hline Pohnpei & $6-7^{\circ} \mathrm{N}$ & & $141-187$ & 105 & & Perrine (1978) \\
\hline New Guinea & $6-7^{\circ} \mathrm{S}$ & & & & $85-190$ & Quinn \& Kojis (1987) \\
\hline Sri Lanka & $7^{\circ} \mathrm{N}$ & $120-130$ & & & & Jayamanna \& Jinadasa (1993) \\
\hline Tropical Australia (north) & $11-15^{\circ} \mathrm{S}$ & & $120-209$ & & & Hill (1994) \\
\hline Madagascar & $13^{\circ} \mathrm{S}$ & & & & $102-180$ & Le Reste et al. (1976) \\
\hline New Caledonia & $20-22^{\circ} \mathrm{S}$ & $126\left(140^{*}\right)$ & & & & Delathiere (1990) \\
\hline Subtropical Australia & $28^{\circ} \mathrm{S}$ & & & & $138(147 *)$ & Heasman (1980) \\
\hline South Africa & $28^{\circ} \mathrm{S}$ & $116\left(145^{*}\right)$ & & & & Davis et al. (2004) \\
\hline South Africa & $29^{\circ} \mathrm{S}$ & & & & $104(123 *)$ & Robertson \& Kruger (1994) \\
\hline South Africa & $32-33^{\circ} \mathrm{S}$ & & & & $130-140$ & Robertson (1996) \\
\hline South Africa & $34^{\circ} \mathrm{S}$ & & $137-159$ & $103-148$ & & Hill (1975) \\
\hline South Africa & $34^{\circ} \mathrm{S}$ & & & & $131-141$ & Du Plessis (1971) \\
\hline
\end{tabular}

Size measured as carapace width in $\mathrm{mm}$

* Size at $50 \%$ maturity

Table 4 Maturity stages of gonads in male Scylla serrata (adapted from Shanmugam \& Bensam, 1980)

\begin{tabular}{llll}
\hline Stage & Color & External characteristics & Histology \\
\hline I Immature & Transparent, creamy & Testes occupy $\leq 1 / 6$ th of haemocoel & $\begin{array}{c}\text { Adhering to the lobes of hepatopancreas } \\
\text { without prominent vas deferens }\end{array}$ \\
II Maturing & Creamy white & Testes occupy $1 / 4$ th to $1 / 3$ rd of haemocoel & \\
III Mature & Milky white & Testes occupy $1 / 2$ to full haemocoel & With a thick vas deferens \\
\hline
\end{tabular}

genital openings (Du Plessis, 1971; Lavina, 1978b). Multiple spawning after a single mating has been observed in the female mud crab (Du Plessis, 1971; Brick, 1974), indicating that females can store sperm, which is a common feature in larger decapod crustaceans (Raviv et al., 2008).

\section{Sex ratios and density}

In unfished populations, female mud crabs can be three-fold outnumbered by males, for example in Kosrae, Micronesia the male: female ratio can be as high as 3:1 (Bonine et al., 2008). Similar ratios have been reported from other studies (Heasman, 1980). By contrast, in areas with a sex-biased fishery, a strong shift toward female-dominated populations is found. In Queensland, Australia, the fishing regulations only allow large ( $\geq 150 \mathrm{~mm} \mathrm{CW}$ ) males to be taken, which results in increasing numbers of large females compared to males. This shift can be reversed with the implementation of marine protected areas (MPAs) where fishing is prohibited (Pillans et al., 2005; Butcher et al., 2014; Alberts-Hubatsch, pers. observation).

Population densities and biomass are often difficult to measure, and only few studies have addressed this issue. Abundances and biomass can be important indicators for the health of the species as well as the whole ecosystem (Butcher et al., 2003; Walton et al., 2007). Low densities from 0.2 to 2.4 crabs per hectare were reported from North Australia, depending on the season and the activity of the mud crabs (Tait et al., 1985), while densities as high as 40 crabs per hectare were observed in Palau (Ewel et al., 2009). This report coincides with earlier studies, which reported densities of 44-53 crabs per hectare for Natal, South Africa (Robertson \& Piper, 1991) and 80 crabs per hectare for another South African estuary (Kleinemond estuary, Hill, 1975). Maximum densities were found in Tanzania with $1228 \pm 7.3$ crabs per hectare $( \pm S D)$ at the mangrove fringe and $324 \pm 10$ crabs per hectare in the 
Table 5 Ovary development female Scylla serrata, GSI = gonadosomatic index. (adapted from Prasad \& Neelakantan, 1989; Poovachiranon, 1992; Robertson \& Kruger, 1994; Quinitio et al., 2007)

\begin{tabular}{|c|c|c|c|c|c|}
\hline Stage & Color & GSI & $\begin{array}{l}\text { Ova } \\
\text { diameter } \\
(\mathrm{mm})\end{array}$ & External characteristics & Histology \\
\hline 0 & Translucent & & & & $\begin{array}{l}\text { Clusters of oogonia, primary oocytes } \\
\text { surrounded by follicle cells apparent in the } \\
\text { ovarian lobe; pre-vitellogenic stage in some } \\
\text { developing oocytes }\end{array}$ \\
\hline I Immature & $\begin{array}{l}\text { Transparent, } \\
\text { white }\end{array}$ & $\leq 0.5$ & $0.01-0.06$ & $\begin{array}{l}\text { Ovaries thin strips, covering } \\
10 \% \text { of haemocoel }\end{array}$ & $\begin{array}{l}\text { Cluster of oogonia and primary oocytes, } \\
\text { surrounded by connective tissue; more } \\
\text { advanced oocytes in the periphery; first yolk } \\
\text { globules previtellogenic oocytes }\end{array}$ \\
\hline $\begin{array}{l}\text { II Early } \\
\text { maturing }\end{array}$ & $\begin{array}{l}\text { Yellow to } \\
\text { orange/ } \\
\text { pinkish }\end{array}$ & $0.5-1.5$ & $0.10-0.30$ & $\begin{array}{l}\text { Ovaries increase in size, } \\
\text { covering } 20 \% \text { of haemocoel }\end{array}$ & $\begin{array}{l}\text { Most bigger oocytes yolk-filled; follicle cells } \\
\text { surround each oocyte }\end{array}$ \\
\hline $\begin{array}{l}\text { III Late } \\
\text { maturing }\end{array}$ & Orange & $2.5-8.0$ & $0.40-0.90$ & $\begin{array}{l}\text { Ovaries extending into } \\
\text { anterolateral region of } \\
\text { carapace, covering } 50 \% \text { of } \\
\text { haemocoel }\end{array}$ & $\begin{array}{l}\text { Yolk globules occur in the cytoplasm, follicle } \\
\text { cells hardly discernible; some atretic cells } \\
\text { evident }\end{array}$ \\
\hline $\begin{array}{l}\text { IV Fully } \\
\text { mature }\end{array}$ & $\begin{array}{l}\text { Orange to } \\
\text { deep } \\
\text { orange/ } \\
\text { reddish }\end{array}$ & 15.85 & $0.70-1.30$ & $\begin{array}{l}\text { Ovaries covering } 80-100 \% \text { of } \\
\text { haemocoel; eggs visible to } \\
\text { the naked eye }\end{array}$ & $\begin{array}{l}\text { Large yolk globules in entire cytoplasm; } \\
\text { nucleus small; follicle cells hardly } \\
\text { discernible; some atretic cells evident }\end{array}$ \\
\hline V Spent & $\begin{array}{l}\text { Yellow, } \\
\text { orange to } \\
\text { brown }\end{array}$ & & & Flaccid ovary & $\begin{array}{l}\text { Some unspawned oocytes of various stages } \\
\text { present, some atretic cells evident }\end{array}$ \\
\hline
\end{tabular}

inner mangroves, resulting in biomass estimates of 604 and $188 \mathrm{~kg}$ per hectare, respectively (Barnes et al., 2002). The high discrepancies in abundances might be due to both different sampling techniques (catching technique and effort, sampling intertidal or subtidal areas or both, sampling time) and/or actual differences in densities induced by habitat or environmental conditions.

\section{Feeding and trophic role}

Mud crabs are top benthic predators and feed on sessile or slow-moving benthic macroinvertebrates, mainly gastropods, crustaceans, and molluscs, as shown by foregut content analyses conducted on populations in Australia, Africa, and India (Hill, 1976; McLaren, 1977; Prasad \& Neelakantan, 1988). The composition of food items changes as the mud crab grows (Prasad \& Neelakantan, 1988). In small juveniles ( $<70 \mathrm{~mm} \mathrm{CW})$, foregut contents were dominated by detritus while in larger juveniles $(>80 \mathrm{~mm} \mathrm{CW})$ and adults, crustaceans and fish were the dominant food items. This change in the food composition was confirmed by stable isotope analyses in Thailand (Thimdee et al., 2001). Small mud crabs are omnivorous, feeding opportunistically on smaller crabs and plants, whereas medium- and large-sized crabs are carnivorous, feeding on benthic invertebrates (Thimdee et al., 2001) or being opportunistic scavengers (Webley, 2008).

Some authors suggested that mud crabs are predominantly feeding at night, and in laboratory experiments, mud crabs spend the daytime buried in sand and became active during the night (Hill, 1976, 1979b). In the wild, the catchability of mud crabs does not change over the day's cycle probably due to turbid waters, which suggests no periodicity in the feeding activity (e.g., south-east Australia; AlbertsHubatsch, pers. observation).

Endo- and epibenthic food items are detected by the chemoreceptors in the mud crabs walking legs. Mud crabs seem to exhibit responses toward olfactory cues of prey items by displaying searching behavior (mainly locomotion and tactile investigation; Wall et al., 2009) to find the approximate location of the food item. 
Laboratory observations revealed that the crab then starts drilling in the sand with the dactyls of its walking legs until it finds the exact location of a food item, and pushes it out of the sand with its chela (Hill, 1979b). Compared with other portunid crabs, mud crabs have relatively heavy and blunt chelae (Heasman, 1980), which allow them to crush the hard shells of bivalves and gastropods to feed on them (Williams, 1978).

In most regions, the activity, and therewith the feeding of mud crabs, is strongly linked to the wet season, which is the most productive season in the tropics (summer). The feeding rate drops with decreasing temperatures during the winter and ceases when temperature is below $12^{\circ} \mathrm{C}$ (Du Plessis, 1971; Hill, 1980). Feeding increases again when the water becomes warmer in the spring and during summer $(\mathrm{Du}$ Plessis, 1971).

The feeding rate also ceases $2-14$ days before molting. Shortly after molting (2-4 days), the crab starts feeding again, when the mouthparts have hardened (Du Plessis, 1971). Females do not feed when they are ovigerous, showing a similar behavior to that of molting crabs (Du Plessis, 1971).

Little is known about turnover rates of mud crabs and the systemic importance for mangrove ecosystems, i.e., the role of mud crab for ecosystem functioning (e.g., consumption and turnover of biomass). The monthly consumption rates for intermediate sized crabs (368-678 $\mathrm{g}$ wet weight) varies from $0.13 \mathrm{~g}$ food* $\mathrm{g} \mathrm{crab}^{-1}$ in winter to $0.41 \mathrm{~g}^{\text {food* }} \mathrm{g} \mathrm{crab}^{-1}$ in summer (average $0.29 \mathrm{~g}$ food $^{*} \mathrm{~g} \mathrm{crab}^{-1}$ per month) at ambient water temperatures in the laboratory ( $\mathrm{Du}$ Plessis, 1971). Taken these experimental numbers to the field, mud crabs increase their weight from 360 to $680 \mathrm{~g}$ within a year while consuming $1.74 \mathrm{~kg}$ of prey. Combining this number with the lowest estimate for biomass of $188 \mathrm{~kg} / \mathrm{hectare}$ inside the mangrove forest (Barnes et al., 2002) would result in $654.2 \mathrm{~kg}$ biomass consumed by mud crabs per hectare and year. At the mangrove fringe, the amount of biomass consumed by mud crabs per hectare per year would be even greater, at $2101.9 \mathrm{~kg}$ (604 kg of crab biomass per hectare; Barnes et al., 2002). These figures are likely to vary strongly between regions and can only provide guidance on the potential importance of mud crabs in estuarine ecosystems. However, the significance of the trophic role of mud crabs for mangrove ecosystem functioning has rarely been studied. Only one study investigated the scavenging potential of mud crabs, and estimated its role rather insignificant, assuming that it could be easily replaced by other scavenging or decomposing organisms (Webley, 2008). However, that study only estimated the role of $S$. serrata as scavenger, not as a predator in general.

The predation on mud crabs is the highest when they are juveniles and decreases with the increase of size (Palmqvist, 2009), but even large mud crabs are preyed upon by aquatic top predators such as crocodiles and sharks (Hill, 1979a). In South Africa, the water mongoose Atilax paludinosus has been found to feed on mud crabs as well (Whitfield \& Blaber, 1980). In the intertidal zone, birds like the Grey Heron (e.g., Egretta novaehollandiae, Butorides striatus) are common predators on small crabs (Hill, 1979a). Many mud crabs are also subject to intraspecific predation-mud crabs are well known for their cannibalistic behavior, which hinders rearing them in high densities in aquaculture (Quinitio et al., 2001; Allan \& Fielder, 2003; Mann et al., 2007).

\section{Growth}

Like all decapod crustaceans, S. serrata has an exoskeleton (cuticle), which makes molting a prerequisite for growth. Prior to molting (4-6 h before) the crab reduces all activities and completely stops feeding (Lavina, 1978a; Mirera \& Mtile, 2009), and experiences a general weight decrease (Mirera \& Mtile, 2009). The loss of weight can be allocated to the extrusion of water prior to molting. This also applies to protein levels in the hemolymph (i.e., oxyhemocyanin), which increase before molting as do the osmolality levels (Chen \& Chia, 1997). In the reverse direction, hemolymph protein and electrolyte levels decrease after molting, which is associated with postmolt water uptake (Chen \& Chia, 1997).

The molting follows a rhythmic pattern and is closely related to the lunar and tidal cycles (Le Reste et al., 1976; Mirera \& Mtile, 2009), most crabs molt during the neap high tide during night (Mirera \& Mtile, 2009). In the intertidal zone, mud crabs exclusively molt at high tide, so they are covered with water. Molting is an important factor for the reproduction process as female crabs need to be soft-shelled to be inseminated (see reproduction). The process of molting is necessary for growth, but also poses a high risk for the mud crabs. The molting crab is very 
vulnerable to predators, and especially during the larval stages, there are high mortality rates due to molting (Hamasaki, 2003).

Mud crabs can easily reach sizes above $200 \mathrm{~mm}$ $\mathrm{CW}$, and maximum reported sizes seem to be slightly different in the different regions (228 mm in Pohnpei, Perrine, 1978; 230 mm in Kosrae, Bonine et al., 2008; 206 and $209 \mathrm{~mm}$ in Australia, Heasman, 1980; Hill, 1994; 200 mm in South Africa, Robertson \& Kruger, 1994). Growth rates of males and females are similar (Mirera \& Mtile, 2009), but as in many other brachyuran crab species, adult male mud crabs are generally heavier than females of the same size due to their bigger chelae (sexual dimorphism; Schenk \& Wainwright 2001). Juvenile mud crabs molt frequently which results in a high growth rate, but there is a decrease in molt frequency with the increase of age. Intermolt duration of four to seven days was observed for instar III mud crabs $(8-13 \mathrm{~mm} \mathrm{CW})$ under optimal conditions (Ruscoe et al., 2004) and 18 days intermolt duration between the first two molts of larger juveniles (initial size approx. $40 \mathrm{~mm} \mathrm{CW}$ ) increasing to 50-60 days between 2 nd and 3rd molts (from 50 to $65 \mathrm{~mm} \mathrm{CW}$; Catacutan, 2002). In the Philippines, mud crabs reached maturity in captivity within 146 days after hatching into the first crab stage and the calculated duration from egg to mature crab covered approx. 186 days with twelve-fifteen molts (Arriola, 1940).

With the increase of intermolt duration with the increasing age, there is an increase of growth increments. Mud crabs with a mean initial size of $67 \mathrm{~mm}$ $\mathrm{CW}$ are growing by an average of $15 \mathrm{~mm} \mathrm{CW}$ after each molt, whereas crabs with mean sizes of 103 and $131 \mathrm{~mm} \mathrm{CW}$ are growing by 20 and $23 \mathrm{~mm}$, respectively (Du Plessis, 1971).

\section{Conclusions and future challenges}

Throughout its life, S. serrata undergoes several ontogenetic shifts, expressing different behaviors and occupying different habitats at each stage (Fig. 2): I.) the larvae are (presumably) released offshore, and undergo five larval stages before returning to coastal areas; II.) The larvae metamorphose into the megalopa stage in these coastal areas and subsequently settle and transform into the first juvenile stage in supposedly inshore areas; III.) Early juvenile mud crabs inhabit sheltered mangrove areas, and IV.) they expand their habitat to larger subtidal and intertidal areas in or adjacent to mangrove habitat when growing into an adult crabs. V.) After mating, the male resides in inshore waters, whereas the female sets out to spawn at sea ('spawning migration'). The differences in habitat use are mainly driven by life-stage-dependent tolerances as well as intraspecific competition (cannibalism).

Although a number of publications discuss the biology of developmental stages, these are mainly interested in aquaculture purposes, e.g., best survival rates. Little information is available about the behavior and habitat use of the early life stages in the wild. Recent studies were able to detect the habitat use of small crabs, but it is also crucial to know how small juvenile crabs would react to alterations of this environment (e.g., habitat fragmentation). The survival of the species depends greatly on successful recruitment to the adult population, and therefore more knowledge is needed on larval transport, settlement process, habitat use, adaptability to changing environment, and recruitment mechanisms.

There are still some gaps in knowledge about adult habitat use and behavior. It is still not clear how and why burrows are used, and if there are different types of mud crab behavior (i.e., mud crabs using burrows vs. mud crabs not using burrows) or if there is even a shift in behavior from use of burrows to non-use of burrows depending on, e.g., the crab size or changes in environmental conditions. Furthermore, knowledge of spawning behavior of female crabs is vague, and it is not known if females only migrate when gravid; where their spawning grounds are, and which orientation mechanisms (e.g., rheotaxis, use of olfactory, auditory or celestial cues) are used to find appropriate spawning grounds.

Finally, upon reviewing the systemic role of mud crabs, it became evident that many facts on this topic remain undefined. Abundances seem to vary substantially between areas, but it is not known why and what this means for the persistence or status of the mud crab population or the ecosystem. In the light of this information gap, the development of a standardized sampling method for determining mud crab abundances is necessary to compare the role of the mud crab over (geographic) different ecosystems. Even though it is known that the mud crab is a top benthic predator, not much is known about its systemic role. Besides the suggested insignificant systemic role as a 
scavenger (Webley, 2008), it is not known what consequences the absence of mud crabs on the estuarine ecosystem would have. Therefore a number of different variables would have to be investigated, starting with maximum and average size of mud crabs in the respective geographic area, as well as densities, biomass, food composition, and food intake.

Most studies neglect the fact that the species shows high variations in terms of size, maturity, spawning seasonality, and also exposure to human exploitation at different locations throughout its range. Scylla serrata occurs on three different continents, but to date no comparative studies have been conducted among the different locations. Regarding the apparent differences (e.g., size at maturity, thermal tolerances of larvae, abundances) it is not known if these can be attributed to differences in sampling methods, actual genetic differentiation, or phenotypic plasticity. Unraveling the geographic differences could also help to predict changes in mud crab populations and their reactions toward changing environmental parameters, as these may have already been reflected in another geographic area where mud crabs occur.

While climate change and global warming are widely accepted to cause significant changes to ecosystems globally and may impact on the persistence of marine species (Vitousek, 1994; Walther et al., 2002; Harley et al., 2006), this subject is hardly discussed in mud crab research, except few papers discussing annual variations (Meynecke et al., 2010, 2012). Rising temperatures are known to be a problem for many crustacean species from temperate regions (e.g., Walther et al., 2010). However, S. serrata might not be affected given that all life stages are highly tolerant toward warm and increasing temperatures, as it is typical for warm water crustaceans (Anger, 2001). Yet, the absorption of atmospheric $\mathrm{CO}_{2}$ lowers $\mathrm{pH}$ in seawater ('ocean acidification') and can have negative effects on calcification rates of a variety of marine species, including crustaceans (Ries et al., 2009; Byrne, 2011). Even though crustaceans with a relative thick epicuticle seem to be less affected (e.g., Ries et al., 2009; Small et al., 2010), this has not been investigated to date for $S$. serrata and could be of particular concern for larvae and early life stages. Further, ocean acidification is known to alter the sensory abilities and therefore the behavior of marine organisms. Tropical fish larvae, for which larval sensory abilities are well studied, showed diminished olfactory discrimination abilities under elevated $\mathrm{CO}_{2}$ concentrations, and therefore loss of crucial cognitive abilities (Munday et al., 2009; Simpson et al., 2011; Ferrari et al., 2012). So far, these issues have received no attention in mud crab research.

Mangrove ecosystems as the primary habitat of mud crabs might experience a decline in total area due to sea-level rise (Gilman et al., 2008), potentially resulting in habitat loss for mud crabs. However, nonclimate-related anthropogenic stressors such as habitat loss and fragmentation due to logging and urbanization and pollution (e.g., urban discards, toxins, microplastics) might have a greater impact on mangrove ecosystems and therefore mud crabs. Water pollution for example may also influence settlement behavior and success of mud crab larvae by altering olfactory settlement cues, as known to be the case with fish larvae (Olsén, 2011; Siebeck et al., 2015).

This review covers a number of aspects relating to the ecology of $S$. serrata. It becomes evident that there are still essential gaps in knowledge about life history, behavior, habitat use, and the significance for the inhabited ecosystem. In summarizing apparent knowledge gaps, we emphasize the pressing need for further research in a multitude of areas relating to $S$. serrata. The information gained from addressing these missing links is vital for researchers, decision-makers, and practitioners in order to develop appropriate and effective mangrove and mud crab management strategies.

Acknowledgements The authors would like to thank two anonymous reviewers for helpful comments on the manuscript. KD received funding from the MASTS pooling initiative (The Marine Alliance for Science and Technology for Scotland), and its support is gratefully acknowledged. MASTS is funded by the Scottish Funding Council (grant reference HR09011) and contributing institutions.

Open Access This article is distributed under the terms of the Creative Commons Attribution 4.0 International License (http:// creativecommons.org/licenses/by/4.0/), which permits unrestricted use, distribution, and reproduction in any medium, provided you give appropriate credit to the original author(s) and the source, provide a link to the Creative Commons license, and indicate if changes were made.

\section{References}

Alberts-Hubatsch, H., S. Y. Lee, K. Diele, M. Wolff \& I. Nordhaus, 2014. Microhabitat use of early benthic stage 
mud crabs, Scylla serrata (Forskål, 1775), in eastern Australia. Journal of Crustacean Biology 34: 604-610.

Allan, G., \& D. Fielder, 2003. Mud crab aquaculture in Australia and Southeast Asia. In Allan, G., \& D. Fiedler (eds), Proceedings of a Scoping Study and Workshop. ACIAR Working Paper No.54. Australian Centre for International Agricultural Research, Joondooburri Conference Centre, Bribie Island.

Anand, A., S. G. Wesely \& S. Satheesh, 2006. Notes on a commercially valuable crab Scylla serrata (Forskal, 1775) and two poisonous crabs, Zosimus aeneus (Linnaeus, 1758) and Platypodia granulosa (Rüppell, 1830) from Laamu Atoll, Maldives. Maledives Marine Research Bulletin 8: 37-53.

Anger, K., 2001. The biology of decapod crustacean larvae. In Vonk, R. (ed.), Crustacean Issues. A.A. Balkema Publishers, Lisse.

Arriola, F. J., 1940. A preliminary study of the life history of Scylla serrata (Forskal). The Phillipine Journal of Science 73: 437-456.

Barnes, D. K. A., N. K. Dulvy, S. H. Priestley, W. R. T. Darwall, V. Choisel \& M. Whittington, 2002. Fishery characteristics and abundance estimates of the mangrove crab Scylla serrata in Southern Tanzania and Northern Mocambique. South African Journal of Marine Science 24: 19-25.

Baylon, J. C., 2010. Effects of salinity and temperature on survival and development of larvae and juveniles of the mud crab, Scylla serrata (Crustacea: Decapoda: Portunidae). Journal of the World Aquaculture Society 41: 858-873.

Bonine, K. M., E. P. Bjorkstedt, K. C. Ewel \& M. Palik, 2008. Population characteristics of the mangrove crab Scylla serrata (Decapoda: Portunidae) in Kosrae, Federated States of Micronesia: effects of harvest and implications for management. Pacific Science 62: 1-19.

Brick, R. W., 1974. Effects of water quality, antibiotics, phytoplankton and food survival and development of larvae of Scylla serrata (Crustacea: Portunidae). Aquaculture 3: 231-244.

Brown, I. W., 1993. Mangrove crabs. In Wright, A., \& L. Hill, (eds), Nearshore Marine Resources of the South Pacific. Institute of Pacific Studies (Suva), Forum Fisheries Agency (Honiara) and the International Centre for Ocean Development (Canada), 710: 609-642.

Butcher, P. A., A. J. Boulton, \& S. D. A. Smith, 2003. Mud crab (Scylla serrata: Portunidae) populations as indicators of the effectiveness of estuarine marine protected areas. World Congress on Aquatic Protected Areas proceedings: 421-427.

Butcher, P. A., A. J. Boulton, W. G. Macbeth \& H. A. Malcolm, 2014. Long-term effects of marine park zoning on giant mud crab Scylla serrata populations in three Australian estuaries. Marine Ecology Progress Series 508: 163-176.

Byrne, M., 2011. Impact of ocean warming and ocean acidification on marine invertebrate life history stages: vulnerabilities and potential for persistence in a changing ocean. Oceanography and Marine Biolog: an Annual Review 49: $1-42$.

Catacutan, M. R., 2002. Growth and body composition of juvenile mud crab, Scylla serrata, fed different dietary protein and lipid levels and protein to energy ratios. Aquaculture 208: 113-123.
Chen, J. C. \& P. G. Chia, 1996a. Hemolymph ammonia and urea and nitrogenous excretions of Scylla serrata at different temperature and salinity levels. Marine Ecology Progress Series 139: 119-125.

Chen, J.-C. \& P.-G. Chia, 1996b. Oxygen uptake and nitrogen excretion of juvenile Scylla serrata at different temperature and salinity levels. Journal of Crustacean Biology 16: 437-442.

Chen, J.-C. \& P.-G. Chia, 1997. Oxyhemocyanin, protein, osmolality and electrolyte levels in the hemolymph of Scylla serrata in relation to size and molt cycle. Journal of Experimental Marine Biology and Ecology 217: 93-105.

Davenport, J. \& T. M. Wong, 1987. Responses of adult mud crabs (Scylla serrata) (Forskal) to salinity and low oxygen tension. Comparative Biochemistry and Physiology 86A: 43-47.

Davis, J. A., G. J. Churchill, T. Hecht \& P. Sorgeloos, 2004. Spawning characteristics of the South African mudcrab Scylla serrata (Forskal) in captivity. Journal of the World Aquaculture Society 35: 47.

DeFelice, R. C., L. G. Eldredge, J. T. Carlton, \& H. Bishop Museum, 2001. Guidebook to the introduced marine species in Hawaiian waters-Nonindigenous marine invertebrates. Bishop Museum Technical Report.

Delathiere, S., 1990. Biologie et exploitation du crabe de paletuviers Scylla serrata en Nouvelle Caledonie. PhD thesis. Université de Bretagne Occidentale. Doctoral thesis.

Demopoulos, A. W. J., N. Cormier, K. C. Ewel \& B. Fry, 2008. Use of multiple chemical tracers to define habitat use of Indo-Pacific mangrove crab, Scylla serrata (Decapoda: Portunidae). Estuaries and Coasts 31: 371-381.

DeVries, M. C., R. A. Tankersley, J. R. B. Forward, W. W. Kirby-Smith \& R. A. Luettich Jr, 1994. Abundance of estuarine crab larvae is associated with tidal hydrologic variables. Marine Biology 118: 403-413.

Du Plessis, A., 1971. A preliminary investigation into the morphological characteristics, feeding, growth, reproduction and larval rearing of Scylla serrata Forskal (Decapoda: Portunidae), held in captivity. Fisheries Development Corporation of South Africa, unpublished report. pp. 78.

Estampador, E. P., 1949. Studies on Scylla (Crustacea: Portunidae) I. Revision of the genus. The Phillipine journal of science 78: 95-109.

Ewel, K. C., 2008. Mangrove crab (Scylla serrata) populations may sometimes be best managed locally. Journal of Sea Research 59: 114-120.

Ewel, K. C., S. Rowe, B. McNaughton \& K. M. Bonine, 2009. Characteristics of Scylla spp. (Decapoda: Portunidae) and their mangrove forest habitat in Ngaremeduu Bay, Republic of Palau. Pacific Science 63: 15-26.

Fabricius, J. C., 1789. Supplementum Entomologiae Systematicae. Proft \& Storch. Hafniae. pp. 1-572.

FAO, 2012. Fisheries and aquaculture information and statistics service., http://www.fao.org/fishery/statistics/en.

Ferrari, M. C. O., R. P. Manassa, D. L. Dixson, P. L. Munday, M. I. McCormick, M. G. Meekan, A. Sih \& D. P. Chivers, 2012. Effects of ocean acidification on learning in coral reef fishes. PloS One 7: e31478.

Fondo, E. N., E. N. Kimani \& D. O. Odongo, 2010. The status of mangrove mud crab fishery in Kenya, East Africa. International Journal of Fisheries and Aquaculture 2: 79-86. 
Forskål, P., 1775. Insecta, Brachyuri, 41. Cancer serratus Descriptiones Animalium. p. 90.

Fratini, S., L. Ragionieri \& S. Cannicci, 2010. Stock structure and demographic history of the Indo-West Pacific mud crab Scylla serrata. Estuarine, Coastal and Shelf Science 86: 51-61.

Fuseya, R. \& S. Watanabe, 1996. Genetic variability in the mud crab genus Scylla (Brachyura: Portunidae). Fisheries Science 62: 705-709.

Fuseya, R., T. Sakamoto, S. Dan, M. Tamaki, T. Hayashibara \& M. Katoh, 2007. Development and characterization of microsatellite markers from mud crab Scylla serrata for population genetics. Aquaculture 272: 38-57.

Gilman, E. L., J. Ellison, N. C. Duke \& C. Field, 2008. Threats to mangroves from climate change and adaptation options: A review. Aquatic Botany 89: 237-250.

Gopurenko, D. \& J. M. Hughes, 2002. Regional patterns of genetic structure among Australian populations of the mud crab, Scylla serrata (Crustacea: Decapoda): evidence from mitochondrial DNA. Marine and Freshwater Research 53: 847-857.

Gopurenko, D., J. M. Hughes \& L. Bellchambers, 2003. Colonisation of the southwest Australian coastline by mud crabs: evidence for a recent range expansion or humaninduced translocation? Marine and Freshwater Research. 54: 833-840.

Gopurenko, D., J. M. Hughes \& C. P. Keenan, 1999. Mitochondrial DNA evidence for rapid colonisation of the IndoWest Pacific by the mudcrab Scylla serrata. Marine Biology 134: 227-233.

Hamasaki, K., 2003. Effects of temperature on the egg incubation period, survival and developmental period of larvae of the mud crab Scylla serrata (Forskal) (Brachyura: Portunidae) reared in the laboratory. Aquaculture 219: 561-572.

Harley, C. D. G., R. A. Hughes, K. M. Hultgren, B. G. Miner, C. J. B. Sorte, C. S. Thornber, L. F. Rodriguez, L. Tomanek \& S. L. Williams, 2006. The impacts of climate change in coastal marine systems. Ecology Letters 9: 228-241.

Heasman, M. P., 1980. Aspects of the general biology and fishery of the mud crab Scylla serrata (Forskal) in Moreton Bay, Queensland. PhD thesis, University of Queensland.

Heasman, M. P., D. R. Fielder \& R. K. Shepherd, 1985. Mating and spawning in the mudcrab, Scylla serrata (Forskål) (Decapoda: Portunidae), in Moreton Bay, Queensland. Journal of Freshwater and Marine Research 36: 773-783.

Herbst, J. F., 1796. Versuch einer Naturgeschichte der Krabben und Krebse. Nebst einer systematischen Beschreibung ihrer verschiedenen Arten, Volume 3. Zurich.

Hill, B. J., 1974. Salinity and temperature tolerance of zoeae of the portunid crab Scylla serrata. Marine Biology 25: 21-24.

Hill, B. J., 1975. Abundance, breeding and growth of the crab Scylla serrata in two South African estuaries. Marine Biology 32: 119-126.

Hill, B. J., 1976. Natural food, foregut clearance-rate and activity of the crab Scylla serrata. Marine Biology 34: 109-116.

Hill, B. J., 1979a. Biology of the crab Scylla serrata (Forskal) in the St. Lucia system. Transactions of the Royal Society of South Africa 44: 55-62.

Hill, B. J., 1979b. Aspects of the feeding strategy of the predatory crab Scylla serrata. Marine Biology 55: 209-214.
Hill, B. J., 1980. Effects of temperature on feeding and activity in the crab Scylla serrata. Marine Biology 59: 189-192.

Hill, B. J., 1994. Offshore spawning by the portunid crab Scylla serrata (Crustacea: Decapoda). Marine Biology 120: 379-384.

Hill, B. J., M. J. Williams, P. Dutton \& F. Valley, 1982. Distribution of juvenile, subadult and adult Scylla serrata (Crustacea: Portunidae) on tidal flats in Australia. Marine Biology 120: 117-120.

Hogarth, P. \& M. Beech, 2001. A first modern record of the mangrove crab Scylla serrata in the U.A.E. and southeastern Arabian Gulf. Tribulus 11: 30.

Hyland, S. J., B. J. Hill \& C. P. Lee, 1984. Movement within and between different habitats by the portunid crab Scylla serrata. Marine Biology 80: 57-61.

Ikhwanuddin, M., G. Azmie, H. M. Juariah, M. Z. Zakaria \& M. A. Ambak, 2011. Biological information and population features of mud crab, genus Scylla from mangrove areas of Sarawak, Malaysia. Fisheries Research 108: 299-306.

Imai, H. \& M. Takeda, 2005. A natural hybrid mud crab (Decapoda, Portunidae) from Japan. Journal of Crustacean Biology 25: 620-624.

Imai, H., J. H. Cheng, K. Hamasaki \& K. Numachi, 2004. Identification of four mud crab species (genus Scylla) using ITS-1 and 16S rDNA markers. Aquatic Living Resources 17: $31-34$.

Jayamanna, S. C. \& J. Jinadasa, 1993. Size at maturity and spawning periodicity of the mud crab Scylla serrata (Forskal) in the Negombo Estuary. Journal of the National Science Council of Sri Lanka 21: 141-152.

Kathirvel, M. \& S. Srinivasagam, 1992. Resource and Exploitation of Mud Crab Scylla serrata (Forskal) in India. BOBP, Madras (India): 85-94.

Keenan, C. P., P. Davie \& D. Mann, 1998. A revision of the genus Scylla De Haan, 1833 (Crustacea: Decapoda: Brachyura: Portunidae). The Raffles Bulletin of Zoology 46: 217-245.

Klinbunga, S., A. Boonyapakdee \& B. Pratoomchat, 2000. Genetic diversity and species-diagnostic markers of mud crabs (Genus Scylla) in eastern Thailand determined by RAPD Analysis. Marine Biotechnology Springer New York 2: 180-187.

Knuckey, I. A., 1996. Maturity in male mud crabs, Scylla serrata, and the use of mating scars as a functional indicator. Journal of Crustacean Biology 16: 487-495.

Lavina, A. F., 1978a. Ecdysis of Scylla serrata under artificial conditions. unpublished report.

Lavina, A. F. D., 1978b. Courtship and mating behaviour of Scylla serrata in captivity. unpublished report.

Le Reste, L., L. Feno, \& A. Rameloson, 1976. État de nos connaissances sur le crabe de vase Scylla serrata Forskal à Madagascar. Office de la Recherche Scientifique et Technique Outre-Mer, Paris: Office de la Recherche Scientifique et Technique Outre-Mer (24, rue Bayard, F-75008 Paris).

Lin, Q., S.-J. Li, Z. Li \& G. Wang, 2007. Species composition in genus Scylla from the coast of southeast China. Journal of Fisheries of India 31: 211-219.

Macia, A., P. S. Afonso, J. Paula, \& R. Paula e Silva, 2014. The mud crab Scylla serrata (Forskål) in Maputo Bay, Mozambique. WIOMSA. 
Macintosh, D. J., F. Gonçalves, A. M. V. M. Soares, S. M. Moser, \& N. Paphavisit, 1999. Transport mechanisms of crab megalopae in mangrove ecosystems, with special reference to a mangrove estuary in Ranong, Thailand. Mud Crab Aquaculture and Biology ACIAR Proceedings, Proceedings of an International Scientific Forum, Darwin Australia 78: 178-186.

MacIntosh, D. J., J. L. Overton \& H. V. T. Thu, 2002. Confirmation of two common mud crab species (genus Scylla) in the mangrove ecosystem of the Mekong Delta, Vietnam. Journal of Shellfish Research 21: 259-265.

Mandal, A., M. Varkey, S. P. Sobhanan, A. K. Mani, A. Gopalakrishnan, G. Kumaran, A. Sethuramalingam, P. Srinivasan \& Y. C. T. Samraj, 2014. Molecular markers reveal only two mud crab species of genus Scylla (Brachyura: Portunidae) in Indian coastal waters. Biochemical Genetics 17: 338-354.

Mann, D. L., T. Asakawa, B. Kelly, T. Lindsay \& B. Paterson, 2007. Stocking density and artificial habitat influence stock structure and yield from intensive nursery systems for mud crabs Scylla serrata (Forsskål 1775). Aquaculture Research 38: 1580-1587.

McLaren, E. C. K., 1977. Predation by the crab Scylla serrata (Forskal) on the sessile bivalves Musculus virgiliae (Barnard) and Lamya capensis (Krauss). Zoology II Experimental project. South Africa. Unpublished report.

Meynecke, J.-O. \& S. Y. Lee, 2011. Climate-coastal fisheries relationships and their spatial variation in Queensland, Australia. Fisheries Research 110: 365-376.

Meynecke, J.-O., S. Y. Lee, N. C. Duke \& J. Warnken, 2006. Effect of rainfall as a component of climate change on estuarine fish production in Queensland, Australia. Estuarine, Coastal and Shelf Science 69: 491-504.

Meynecke, J.-O., S. Y. Lee, M. Grubert, I. Brown, S. Montgomery, D. Johnston, \& J. Gillson, 2010. Evaluating the environmental drivers of mud crab (Scylla serrata) catches in Australia. Final Report FRDC Project 2008/012. Australia.

Meynecke, J.-O., M. Grubert, J. M. Arthur, R. Boston \& S. Y. Lee, 2012. The influence of the La Niña-El Niño cycle on giant mud crab (Scylla serrata) catches in Northern Australia. Estuarine, Coastal and Shelf Science 100: 93-101.

Mirera, D. O., 2014. Capture-based mud crab (Scylla serrata) aquaculture and artisanal fishery in East Africa-Practical and ecological perspectives. $\mathrm{PhD}$ thesis, Linnaeus University, Kalmar, Sweden.

Mirera, D. O. \& A. Mtile, 2009. A preliminary study on the response of mangrove mud crab (Scylla serrata) to different feed types under drive-in cage culture system. Journal of Ecology and Natural Environment 1: 7-14.

Mohanty, S. K., A. Mohapatra, R. K. Mohanty, K. S. Bhatta \& A. K. Pattnaik, 2006. Occurrence and biological outlines of two species of Scylla (De Haan) in Chilika lagoon, India. Indian Journal of Fisheries 53: 191-202.

Munday, P. L., D. L. Dixson, J. M. Donelson, G. P. Jones, M. S. Pratchett, G. V. Devitsina \& K. B. Døving, 2009. Ocean acidification impairs olfactory discrimination and homing ability of a marine fish. Proceedings of the National Academy of Sciences of the United States of America 106: 1848-1852.

Naylor, R. L., K. M. Bonine, K. C. Ewel \& E. Waguk, 2002. Migration, markets, and mangrove resource use on Kosrae, Federated States of Micronesia. Ambio 31: 340-350.
Nordhaus, I., F. A. Hadipudjana, R. Janssen \& J. Pamungkas, 2009. Spatio-temporal variation of macrobenthic communities in the mangrove-fringed Segara Anakan lagoon, Indonesia, affected by anthropogenic activities. Regional Environmental Change 9: 291-313.

Nurdiani, R. \& C. Zeng, 2007. Effects of temperature and salinity on the survival and development of mud crab, Scylla serrata (Forsskal), larvae. Aquaculture Research 38: 1529-1538.

Ogawa, C. Y., K. Hamasaki, S. Dan \& S. Kitada, 2011. Fishery biology of mud crabs Scylla spp. at Iriomote Island, Japan: species composition, catch, growth and size at sexual maturity. Fisheries Science 77: 915-927.

Olsén, H., 2011. Effects of pollutants on olfactory mediated behaviors in fish and crustaceans. In Breithaupt, T. \& M. Thiel (eds), Chemical Communication in Crustaceans. Springer, New York: 507-530.

Onyango, S. D., 2002. The breeding cycle of Scylla serrata (Forskal, 1755) at Ramisi River estuary, Kenya. Wetlands Ecology and Management 10: 257-263.

Overton, J. L., 2000. Morphometric, genetic and reproductive characteristics of mud crabs (Genus Scylla de Haan, 1833) from Southeast Asia. PhD thesis, University of Stirling, UK.

Palmqvist, K., 2009. Predation mortality on juvenile mud crab Scylla serrata: Importance of habitat and size. BSc Thesis, University of Gothenburg.

Perrine, D., 1978. The mangrove crab on Ponape. Marine resources division, Ponape, Eastern Caroline Islands marine resources Division, Ponape, Eastern Caroline Is. pp. 66.

Pillans, S., R. D. Pillans, R. W. Johnstone, P. G. Kraft, M. D. E. Haywood \& H. P. Possingham, 2005. Effects of marine reserve protection on the mud crab Scylla serrata in a sexbiased fishery in subtropical Australia. Marine Ecology Progress Series 295: 201-213.

Pineda, J., J. Hare \& S. Sponaugle, 2007. Larval transport and dispersal in the coastal ocean and consequences for population connectivity. Oceanography 20: 22-39.

Poovachiranon, S., 1992. Biological studies of the mud crab Scylla serrata (Forskal) of the mangrove ecosystem in the Andaman Sea. BOBP, Madras (India): 49-57.

Prasad, P. N. \& B. Neelakantan, 1988. Food and Feeding of the Mud Crab Scylla serrata Forskal (Decapoda: Portunidae) from Karwar Waters. Indian Journal of Fisheries 35: 164-170.

Prasad, P. N. \& B. Neelakantan, 1989. Maturity and Breeding of the mud crab, Scylla serrata (Forskal)(Decapoda: Brachyura: Portunidae). Proceedings of the Indian Academy of Science 98: 341-349.

Quinitio, E. T., F. D. Parado-Estepa, O. M. Millamena, E. Rodriguez \& E. Borlongan, 2001. Seed production of mud crab Scylla serrata juveniles. Asian Fisheries Science 14: 161-174.

Quinitio, E. T., J. De Pedro \& F. D. Parado-Estepa, 2007. Ovarian maturation stages of the mud crab Scylla serrata. Aquaculture Research 38: 1434-1441.

Quinn, N. J. \& B. L. Kojis, 1987. Reproductive Biology of Scylla Spp. (Crustacea: Portunidae) from the Labu Estuary in Papua New Guinea. Bulletin of Marine Science 41: 234-241.

Raviv, S., S. Parnes \& A. Sagi, 2008. Coordination of reproduction and molt in decapods. In Mente, E. (ed.), 
Reproductive Biology in Crustaceans. Science Publishers, Enfield.

Rezaie-Atagholipour, M., R. Naderloo, E. Kamrani \& R. Savari, 2013. Preliminary biological information of Scylla serrata (Forskål, 1775) (Brachyura, Portunidae) in the Persian Gulf and Gulf of Oman: a conservation priority. Crustaceana 86: 322-335.

Ries, J. B., A. L. Cohen \& D. C. McCorkle, 2009. Marine calcifiers exhibit mixed responses to $\mathrm{CO} 2$-induced ocean acidification. Geology 37: 1131-1134.

Robertson, W. D., 1996. Abundance, population structure and size at maturity of Scylla serrata (Forskal) (Decapoda: Portunidae) in Eastern Cape estuaries, South Africa. South African Journal of Zoology 31: 177-180.

Robertson, W. D. D. \& A. Kruger, 1994. Size at maturity, mating and spawning in the portunid crab Scylla serrata (Forskal) in Natal, South Africa. Estuarine, Coastal and Shelf Science 39: 185-200.

Robertson, W. D. \& S. E. Piper, 1991. Population estimates of the crab Scylla serrata (Forskål, 1755) (Decapoda: Portunidae) in two closed estuaries in Natal, South Africa, from mark-recapture methods. South African Journal of Marine Science 11(1): 193-202.

Ruscoe, I. M., C. C. Shelley \& G. R. Williams, 2004. The combined effects of temperature and salinity on growth and survival of juvenile mud crabs (Scylla serrata Forskal). Aquaculture 238: 239-247.

Schenk, S. C. \& P. C. Wainwright, 2001. Dimorphism and the functional basis of claw strength in six brachyuran crabs. Journal of Zoology 255: 105-119.

Serene, R., 1952. Les especes du genere Scylla a Nhatrang (Vietnam). Proceedings of Indo-Pacific Fisheries Council. Third meeting, Madras 1951: 113-137.

Shanmugam, S. \& P. Bensam, 1980. On the fishery of the crab Scylla serrata (Forskal) at Tuticorin during 1974-1975. Indian Journal of Fisheries 27: 102-110.

Siebeck, U. E., J. O’Connor, C. Braun \& J. M. Leis, 2015. Do human activities influence survival and orientation abilities of larval fishes in the ocean? Integrative Zoology 10: 65-82.

Simões, N., M. Apel \& D. A. Jones, 2001. Intertidal habitats and decapod faunal assemblages (Crustacea: Decapoda) of Socotra Island, Republic of Yemen. Hydrobiologia 449: 81-97.

Simpson, S. D., P. L. Munday, M. L. Wittenrich, R. Manassa, D. L. Dixson, M. Gagliano \& H. Y. Yan, 2011. Ocean acidification erodes crucial auditory behaviour in a marine fish. Biology Letters 7: 917-920.

Small, D., P. Calosi, D. White, J. I. Spicer \& S. Widdicombe, 2010. Impact of medium-term exposure to $\mathrm{CO} 2$ enriched seawater on the physiological functions of the velvet swimming crab Necora puber. Aquatic Biology 10: 11-21.

Steneck, R. S., 2006. Possible demographic consequences of intraspecific shelter competition among American lobster. Journal of Crustacean Biology 26: 628-638.
Stephenson, W. \& B. Campbell, 1959. The Australian portunids (Crustacea: Portunidae) IV. remaining genera. Australian Journal of Marine and Freshwater Research 11: 73-122.

Sugama, K. \& J. H. Hutapea, 1999. Genetic Characterisation in the mud crab Scylla (Brachyura: Portunidae). Philippine Journal of Science 78: 43-47.

Tait, R. D., B. G. Wallner, \& D. J. Ferrier, 1985. Population biology of the mud crab Scylla serrata (Forskal) in the narrows, Central Queensland. Esso Australia, Rundle Project Group, QLD, Australia.

Taylor, M. L., 1984. New Species of mud crab found in Western Australia. FINS Fisheries News Department of Fisheries and Wildlife, Perth 17: 15-19.

Thimdee, W., G. Deein, C. Sangrungruang \& K. Matsungana, 2001. Stable carbon and nitrogen isotopes of mangrove crabs and their food sources in a mangrove-fringed estuary in Thailand. Benthos Research 56: 73-80.

Vitousek, P. M., 1994. Beyond global warming: ecology and global change. Ecology 75: 1861-1876.

Wall, D., B. Paterson \& R. Mohan, 2009. Behaviour of juvenile mud crabs Scylla serrata in aquaculture: response to odours of moulting or injured crabs. Applied Animal Behaviour Science 121: 63-73.

Walther, G.-R., E. Post, P. Convey, A. Menzel, C. Parmesan, T. J. C. Beebee, J.-M. Fromentin, O. Hoegh-Guldberg \& F. Bairlein, 2002. Ecological responses to recent climate change. Nature 416: 389-395.

Walther, K., K. Anger \& H. Pörtner, 2010. Effects of ocean acidification and warming on the larval development of the spider crab Hyas araneus from different latitudes (54 vs. $79^{\circ}$ N). Marine Ecology Progress Series 417: 159-170.

Walton, M. E., L. Le Vay, J. H. Lebata, J. Binas \& J. H. Primavera, 2007. Assessment of the effectiveness of mangrove rehabilitation using exploited and non-exploited indicator species. Biological Conservation 138: 180-188.

Webley, J. A. C., 2008. The ecology of the mud crab (Scylla serrata): their colonisation of estuaries and role as scavengers in ecosystem processes. $\mathrm{PhD}$ thesis, Griffith University, QLD, Australia.

Webley, J. A. C., R. M. Connolly \& R. A. Young, 2009. Habitat selectivity of megalopae and juvenile mud crabs (Scylla serrata): implications for recruitment mechanism. Marine Biology 156: 891-899.

Whitfield, A. K. \& S. J. M. Blaber, 1980. The diet of Atilax paludinosus (water mongoose) at St Lucia, South Africa. Mammalia 44: 12-15.

Williams, M. J., 1978. Opening of bivalve shells by the mud crab Scylla serrata Forskal. Australian Journal of Marine and Freshwater Research 29: 699-702.

Zafar, M., S. M. N. Amin \& M. M. Rahman, 2006. Population dynamics of mud crab (Scylla serrata) in the southeastern coastal region of Bangladesh. Asian Fisheries Science 19: 43-50. 